\title{
ANALISIS YURIDIS TENTANG HUKUM ASURANSI DALAM TRANSAKSI ELECTRONIC COMMERCE MELALUI PERSPEKTIF KITAB UNDANG-UNDANG HUKUM DAGANG
}

Oleh : Sri Subekti, S.H., M.M., Sp.N., M.H.

\begin{abstract}
Abstrak
Seiring dengan perkembangan teknologi dan informasi di dunia, berbagai hal baru muncul di dalam kehidupan kita sehari-hari. Salah satunya adalah konsep jual beli secara online melalui internet dengan menggunakan E-Commerce. Dengan E-Commerce konsep jual beli tradisonal yang mempertemukan pembeli dan penjual dalam satu ruangan berubah menjadi konsep jual beli jarak jauh atau telemarketing. Dengan adanya konsep ini, tentu saja baik penjual dan pembeli akan merasa di untungkan, karena transaksi jual beli yang terjadi dapat dilakukan 24 jam penuh dengan tidak dibatasi oleh wilayah tertentu. Akan tetapi selain memberikan keuntungan, tentu saja konsep jual beli jarak jauh melalui E-Commerce juga dapat menimbulkan banyak resiko kerugian, salah satunya adalah serangan cyber crime yang dapat menyebabkan penyalahgunaan data para pihak dalam e-commerce sehingga mengalami kerugian.
\end{abstract}

Metode penelitian yang di pakai dalam penulisan makalah ilmiah ini adalah metode Penelitian hukum normatif yang bertujuan untuk menemukan landasan hukum yang jelas dalam meletakkan persoalan yang diangkat, dalam perspektif Kitab Undang-Undang Hukum Dagang, khususnya yang terkait dengan masalah penerapan asuransi dalam transaksi E-Commerce.

Hasil penelitian terungkap bahwa dari pengertian dan batasan tentang asuransi di dalam KUHD, transaksi E-Commerce merupakan obyek yang dapat di asuransikan, karena segala kegiatan didalam transaksi E-Commerce, dapat menimbulkan kehilangan atau kerusakan bagi para pihak yang ada didalamnya.

Pengaturan asuransi mengenai E-Commerce di dalam KUHD sebenarnya perlu diatur secara rinci, sehingga pemerintah hendaknya melakukan revisi Undang-Undang Nomor 40 Tahun 2014 tentang Perasuransian, sehingga dapat memberikan pengaturan jelas mengenai asuransi dalam transaksi bisnis E-Commerce atau cyber insurance.

Kata kunci : e-commerce, asuransi, KUHD 


\title{
JURIDICAL ANALYSIS OF INSURANCE LAW IN ELECTRONIC COMMERCE TRANSACTIONS THROUGH THE PERSPECTIVE OF LAW ON COMMERCIAL LAW
}

\begin{abstract}
Along with the development of technology and information in the world, new things arise in our daily lives. One is the concept of buying and selling online through the Internet using ecommerce. With e-commerce site selling the traditional concept together buyers and sellers in one room transformed into the concept of distance selling or telemarketing. In this concept, both sellers and buyers will feel at profitable, because the sale and purchase transactions that occur do a full 24 hours with not limited by a particular region. However, in addition to providing the advantages, of course, the concept of distance selling via e-commerce can also cause a lot of risk of loss, one of which is the crime of cyber attacks that could lead to misuse of the data of the parties in the e-commerce making a loss.

Research methods in use in the writing of this paper is the normative legal research method aims to find a clear legal basis in putting the issues raised, in particular KUHD perspective on issues related to the implementation of the insurance business transactions through the Internet (E-Commerce).

The results of the study revealed that out of the definition and limits of insurance in the Commercial code, e-commerce transaction is an object that can be insured, because of all the activities in e-commerce transactions, may cause loss or damage to the party in it. Insurance arrangements on e-commerce in the real KUHD regulated in detail so the government should revise Law No. 40 of 2014 on assurance, so as to provide clear regulation on insurance business in e-commerce transactions.
\end{abstract}

Keywords : e-commerce, insurance, KUHD

\section{BAB I PENDAHULUAN}

\section{A. Latar Belakang}

Kegiatan bisnis perdagangan melalui internet yang dikenal dengan istilah Electronic Commerce saat ini merupakan suatu kegiatan yang banyak dilakukan oleh setiap orang, karena transaksi jual beli secara elektronik ini dapat mengefektifkan dan mengefisiensikan waktu sehingga seseorang dapat melakukan transaksi jual beli dengan setiap orang dimanapun dan kapanpun. Semua transaksi jual beli didalam transaksi Electronic Commerce dilakukan tanpa ada tatap muka antara para pihaknya, mereka mendasarkan transaksi jual beli tersebut atas rasa kepercayaan satu sama lain, sehingga perjanjian jual beli yang terjadi diantara para pihak pun dilakukan secara elektronik pula baik melalui e-mail atau cara lainnya, oleh karena itu tidak ada berkas perjanjian seperti pada transaksi jual beli konvensional. Kondisi seperti ini tentu sangat bersiko tinggi, karena, jaringan internet merupakan suatu jaringan terbuka, yang dapat diakses oleh siapa saja dan dimana saja. Resiko kerugian akibat adanya manipulasi data, maupun kerusakan data yang diakibatkan oleh para perentas dunia maya atau yang kita kenal sebagai hacker tentu saja dapat merugikan pihak penyedia layanan e-commerce, penjual, maupun pihak pembeli didalam transaksi electronic commerce.

Untuk itu, dalam rangka menjamin keamanan didalam transaksi electronic commerce muncullah berbagi solusi keamanan seperti Digital Signature, Kunci kriptografis, 
maupun Secure Electronic Transaction (SET) yang di buat oleh penyedia electronic commerce pada website mereka dengan tujuan, untuk melindungi para konsumen. Akan tetapi, berbagai solusi keamanan tersebut tidak memberikan jaminan sepenuhnya kepada perusahaan penyedia electronic commerce untuk terbebas dari kerugian. Tidak adanya jaminan bahwa transaksi ecommerce terbebas dari upaya perusakan/manipulasi data tentu akan berdampak pada turunnya kepercayaan masyarakat terhadap system ini. Padahal dalam trasaksi bisnis di era global seperti sekarang, kepastian dan keamanan merupakan salah satu pilar penompang berkembangnya aktivitas ekonomi.

Sesuai dengan yang disebutkan atas, secara teoritis apapun resiko yang muncul dan mampu menimbulkan kerugian dapat dijadikan obyek asuransi atau dengan kata lain dapat diasuransikan. Ini berarti, segala bentuk transaksi didalam electronic commerce seharusnya dapat di asuransikan untuk dapat menjamin kepastian dan keamanannya dalam bertransaksi, serta memperkecil resiko kerugian yang dapat terjadi. Namun, regulasi yang ada di Indonesia saat ini belum secara jelas mengatur tentang adanya asuransi yang berkaitan dengan electronic commerce atau yang kita kenal dengan istilah cyber insurance. Hal ini dikarenakan Negara Indonesia sampai saat ini masih memakai peraturan perundang-undangan lama peninggalan Negara Belanda dengan azas konkordasi.

Perasuransian dalam perspektif hukum di Indonesia menjadi suatu hal yang menarik untuk diperdalam kaitanya fenomena bahwa dari satu sisi bisnis atau industri asuransi menempatkan posisi regulasi market dalam ruang kehidupan ekonomi namun pada sisi lain regulasi state ditempatkan pada posisi pengaturan untuk menjaga ruang keseimbangan dalam konteks antara pergerakan kehidupan ekonomi ataupun pasar dengan kepentingan perlindungan masyarakat yang membutuhkan ikut campur tangan negara melalui produk hukum.

Tentunya untuk membahas lebih lanjut tidak dapat dilepaskan dari sejarah hukum asuransi di Indonesia, maka dapat dijelaskan yang ditarik dari akar sistem hukum Indonesia, oleh Liliana Tedjosaputro disampaikan bahwa sistem hukum Indonesia berasal dari Hukum Perdata yang dibawa oleh oleh pemerintah kerajaan Belanda ke Indonesia pada masa penjajahan. Dan hukum perdata tersebut dapat ditelusuri akarnya ke Hukum Perdata Prancis ke Hukum Romawi ${ }^{1}$ Keberadaan hukum asuransi di Indonesia berakar dari Kodifikasi Hukum Perdata (Code Civil) dan Hukum Dagang (Code de Commerce) pada permulaan abad ke-19 semasa pemerintah Kaisar Napoleon di Perancis. Pada waktu itu, Hukum Dagang Belanda hanya memuat pasal-pasal mengenai asuransi laut sampai diundangkannya rancangan Kitab Undang-Undang Hukum Dagang (Wet Boek vanKoopenhandel) tahun 1838 yang memuat peraturan-peraturan mengenai asuransi kebakaran, asuransi hasil bumi dan asuransi jiwa. Sistem inilah yang juga dianut untuk Hindia Belanda dahulu yang sampai sekarang masih berlaku di Indonesia ${ }^{2}$.

Asuransi atau pertanggungan timbul karena kebutuhan manusia. Seperti telah dimaklumi, bahwa dalam mengarungi hidup dan kehidupan ini, manusia selalu dihadapkan kepada sesuatu yang tidak pasti, yang mungkin menguntungkan, tetapi mungkin pula sebaliknya. Manusia mengharapkan keamanan atas harta benda mereka, mengharapkan kesehatan dan kesejahteraan tidak kurang sesuatu apa pun, namun

\footnotetext{
1 Liliana Tedjosaputro, Materi Kuliah Kebijakan Hukum Ekonomi, Pada Program Doktor Ilmu Hukum Untag Semarang, 2016

2 Wirjono Prodjodikoro, Hukum Asuransi di Indonesia, Internesa 1986, hal 15.
} 
manusia hanya dapat berusaha, tetapi Tuhan Yang Maha Kuasa yang menentukan segalanya.

Adapun pasal yang mengatur masalah Asuransi atau Pertangungan didalam Kitab Undang-Undang Hukum Dagang (KUHD ) adalah pasal 246 sampai dengan pasal 308 KUHD. Pada pasal 246 Kitab Undang-Undang Hukum Dagang (KUHD) menyebutkan bahwa Asuransi atau pertanggungan adalah perjanjian, di mana penanggung mengikat diri terhadap tertanggung dengan memperoleh premi, untuk memberikan kepadanya ganti rugi karena suatu kehilangan, kerusakan, atau tidak mendapat keuntungan yang diharapkan, yang mungkin akan dapat diderita karena suatu peristiwa yang tidak pasti. Namun pada pasal 247, disebutkan Pertanggungan itu antara lain dapat mengenai: bahaya kebakaran; (KUHD 287 dst.) bahaya yang mengancam hasil pertanian yang belum dipanen; (KUHD 299 dst.) jiwa satu orang atau lebih; (KUHD 302 dst.) bahaya laut dan bahaya perbudakan; (KUHD 592 dst.) bahaya pengangkutan di darat, di sungai, dan perairan pedalaman. (KUHD 686 dst.).

Dari pengertian diatas, dapat kita lihat bahwa KUHD tidak secara jelas mengatur tentang asuransi atau pertangungan yang berkaitan dengan transaksi electronic commerce. Hal ini dikarenakan transaksi electronic commerce baru diperkenalkan di Dunia, pada tahun 1994 dan di Indonesia sendiri baru diperkenalkan sekitar tahun 1996 oleh Dyviacom Intrabum atau D-net. ${ }^{3}$ Padahal, peraturan Perundang-undangan yang dibuat oleh Pemerintah RI tentang asuransi, adalah sesuatu yang sangat relevan untuk diketengahkan dalam makalah ini adalah bagaimana aspek pengaturan dan perjanjian asuransi dalam perspektif hukum di Indonesia, dengan mengkaitkan

3 www.ecomm.lecture.ub.ac.id/2011/11/ diakses pada tanggal 16 November 2016 perbandingan aspek pengaturan dan pelaksanaan muatan Undang-Undang Nomor 2 Tahun 1992 tentang Usaha Perasuransian dengan Undang-Undang Nomor 40 Tahun 2014 tentang Perasuransian maupun dengan kaedah hukum asuransi sebagaimana dalam Kitab Undang-Undang Hukum dagang (KUHD), Kitab Undang-Undang Hukum Perdata (KUHPerdata) sebagai bentuk spektrum hukum. Atas dasar belum pernah ada penelitian hukum yang mengangkat tentang masalah ketidakadaan aturan hukum yang secara khusus mengatur tentang asuransi dalam electronic commerce inilah, akhirnya penulis tertarik untuk mengambil penulisan makalah ilmiah hukum, dengan judul "ANALISIS YURIDIS TENTANG HUKUM ASURANSI DALAM TRANSAKSI ELECTRONIC COMMERCE MELALUI PERSPEKTIF KITAB UNDANG-UNDANG HUKUM DAGANG".

\section{B. Permasalahan}

Beberapa permasalahan yang diambil dalam penulisan makalah ilmiah hukum ini, yaitu:

1. Bagaimana Asuransi dalam transaksi jual beli melalui internet (e-commerce), jika di tinjau dari perspektif Kitab UndangUndang Hukum Dagang (KUHD)?

2. Siapakah pihak yang dapat menjadi subyek dan obyek asuransi dalam transaksi elektronik melalui internet (e-commerce)?

3. Apakah yang menyebabkan asuransi dalam transaksi electronic commerce perlu diatur secara khusus di dalam peraturan perundang-undangan di Indonesia?

\section{BAB II METODE PENELITIAN}

Untuk mengetahui dan penjelasan mengenai adanya segala sesuatu yang berhubungan dengan pokok permasalahan di perlukan suatu pedoman penelitian 
yang disebut metode penelitian yaitu cara melukiskan sesuatu dengan menggunakan pikiran secara seksama untuk mencapai suatu tujuan, sedangkan penelitian adalah suatu kegiataan untuk mencari, merumuskan dan menganalisa sampai menyusun laporan. ${ }^{4}$

Dengan demikian metodologi penelitian sebagai cara yang dipakai untuk mencari, merumuskan dan menganalisa sampai menyusun laporan guna mencapai satu tujuan. Untuk mencapai sasaran yang tepat dalam penelitian penulis menggunakan metode penelitian sebagai berikut :

\section{Jenis Penelitian}

Penelitian yang dilakukan adalah penelitian hukum normatif. Penelitian hukum normatif pada makalah ilmiah ini didasarkan pada bahan hukum primer yaitu dengan cara meinventarisasi pasal-pasal yang berkaitan dengan penerapan asuransi dalam transaksi bisnis melalui internet (E-Commerce) yang terdapat didalam Kitab Undang-Undang Hukum Dagang (KUHD) sebagai dasar regulasi utama. Selain itu dipergunakan juga bahan-bahan tulisan ilmiah lain yang berkaitan dengan penerapan asuransi dalam transaksi bisnis melalui internet (E-Commerce). Penelitian ini bertujuan untuk menemukan landasan hukum yang jelas dalam meletakkan persoalan yang diangkat, dalam perspektif Kitab Undang-Undang Hukum Dagang (KUHD) khususnya yang terkait dengan masalah penerapan asuransi dalam transaksi bisnis melalui internet (E-Commerce).

\section{Pendekatan}

Dalam kaitannya dengan penelitian normatif di sini akan digunakan beberapa pendekatan, yaitu : ${ }^{5}$

1) Pendekatan perundang-undangan

4 Cholid Narbuko, Abu Achmadi, Metode Penelitian Jakarta : Bumi Pustaka, 1997.

5 Johnny Ibrahim, Teori, Metode dan Penelitian Hukum Normatif, Bayumedia Publising, Malang, Jawa Timur, 2007, hlm. 300 (statute approach) Pendekatan perundang-undangan (statute approach) adalah suatu pendekatan yang dilakukan terhadap berbagai aturan hukum yang berkaitan dengan penerapan asuransi dalam transaksi bisnis melalui internet (E-Commerce), seperti : Kitab UndangUndang Hukum Dagang (KUHD), Kitab Undang-undang Hukum Perdata (KUHPdt) , Undang-undang Nomer 2 Tahun 1992 tentang Usaha Perasuransian, Undang-undang Nomer 40 Tahun 2014 tentang Perasuransian, Undang-Undang Nomer 11 Tahun 2008 tentang Informasi dan Transaksi elektronik, Peraturan Pemerintah Nomer 73 Tahun 1992 tentang Penyelesaian Usaha Pengasuransian dan peraturan organik lain yang berhubungan dengan objek penelitian.

1) Pendekatan Konsep (conceptual approach) Pendekatan konsep (conceptual approach) digunakan untuk memahami konsep- konsep tentang : konsep perdagangan dan pemasaran jarak jauh melalui internet (telemarketing). Dengan didapatkan konsep yang jelas maka diharapkan penormaan dalam aturan hukum kedepan tidak lagi terjadi pemahaman yang kabur dan ambigu.

\section{Jenis dan sumber bahan hukum}

Pengumpulan data yang digunakan dalam penyusunan makalah ilmiah ini adalah melalui penelitian kepustakaan (Library Research) untuk mendapatkan konsepkonsep, teori-teori dan informasi-informasi serta pemikiran konseptual dari peneliti pendahulu baik yang berupa peraturan perundang-undangan dan karya ilmiah lainnya. Sumber data kepustakaan diperoleh dari :

a. Bahan Hukum Primer, terdiri dari :

1) Norma atau kaedah dasar ;

2) Peraturan dasar ;

3) Peraturan perundang-undangan yang 
terkait dengan penerapan asuransi dalam perdagangan dan transaksi bisnis melalui internet ( $E$-Commerce), terutama dalam Kitab UndangUndang Hukum Dagang (KUHD), beserta peraturan-peraturan terkait lainnya.

b. Bahan Hukum Sekunder, seperti : hasilhasil penelitian, laporan-laporan, artikel, majalah dan makalah ilmiah, hasil-hasil seminar atau pertemuan ilmiah lainnya yang relevan dengan penelitian ini.

c. Bahan Hukum Tersier atau bahan hukum penunjang yang mencakup bahan yang memberi petunjuk-petunjuk dan penjelasan terhadap bahan hukum primer dan sekunder, seperti kamus umum, kamus hukum serta bahan-bahan primer, sekunder dan tersier di luar bidang hukum yang relevan dan dapat dipergunakan untuk melengkapi data yang diperlukan dalam penelitian ini. Padababini merupakan bab pendahuluan yang menguraikan mengenai hal-hal yang berkaitan dengan Latar Belakang, Perumusan Masalah, Selanjutnya Situs Web juga menjadi bahan bagi penulisan makalah ilmiah ini sepanjang memuat informasi yang relevan dengan penelitian ini.

\section{Teknik Memperoleh Bahan Hukum}

Untuk memperoleh suatu kebenaran ilmiah dalam penulisan makalah ilmiah, maka penulis menggunakan metode pengumpulan bahan hukum dengan cara studi kepustakaan (Library Research), yaitu mempelajari dan menganalisa secara sistematis buku-buku, majalah-majalah, surat kabar, peraturan perundang-undangan dan bahan-bahan lain yang berhubungan dengan materi yang dibahas dalam makalah ilmiah ini.

\section{Teknik Analisis Bahan Hukum}

Teknik analisis bahan hukum yang digunakan dalam penelitian ini adalah analisis kualitatif yaitu mengelompokkan dan menyeleksi data yang diperoleh dari penelitian di lapangan yang kemudian dihubungkan dengan teori-teori, asasasas, dan kaidah-kaidah hukum yang diperoleh dari studi kepustakaan sehingga diperoleh jawaban atas permasalahan yang dirumuskan.

\section{BAB III PEMBAHASAN}

A. Asuransi Dalam Transaksi Elektronik Melalui Internet (E-Commerce) Dalam Prespektif Kitab Undang-Undang Hukum Dagang

Pasal 246 menyebutkan bahwa Asuransi atau pertanggungan adalah perjanjian, di mana penanggung mengikat diri terhadap tertanggung dengan memperoleh premi, untuk memberikan kepadanya ganti rugi karena suatu kehilangan, kerusakan, atau tidak mendapat keuntungan yang diharapkan, yang mungkin akan dapat diderita karena suatu peristiwa yang tidak pasti.

Dari definisi tersebut, kita dapat mengambil 3 unsur tentang pengertian asuransi yaitu :

1) Terdapat suatu kerugian akibat adanya suatu kehilangan, kerusakan, atau tidak mendapatkan keuntungan yang diharapkan akibat dari suatu peristiwa yang tidak pasti terjadi.

2) Pihak tertanggung berjanji membayar uang premi kepada pihak penanggung sekaligus atau dengan angsuran.

3) Pihak penanggung berjanji akan membayar sejumlah uang kepada tertanggung, sekaligus atau secara angsuran jika terjadi / terlaksana unsur pada point a. ${ }^{6}$

Dari pengertian diatas, dapat kita ketahui bahwa transaksi jual beli elektronik atau e-commerce merupakan obyek

$6 \quad$ Wirjono Prodjodikoro, Hukum Asuransi di Indonesia,Bandung,Penerbit PT Intermasa,1987, hal 1 
asuransi, karena segala kegiatan didalam transaksi elektronik atau e-commerce, dapat menimbulkan kehilangan, kerusakan, atau tidak mendapat keuntungan yang diharapkan bagi para pihak yang ada didalamnya. Asuransi dalam transaksi elektronik ini kita kenal sebagai cyber assurance.

Apabila kita analisis dari pihak-pihak yang terlibat di dalam transaksi ecommerce yang antara lain : pembeli, penjual (merchant), issuer, acquirer, dan lembaga otoritas sertifikat (LOS), sesungguhnya pihak yang paling bertanggung jawab atas adanya kerugian didalam transaksi electronic (e-commerce) adalah lembaga otoritas sertifikat (LOS) yang berperan sebagai pengaman transaksi elektronik, karena pihak perusahaan e-commerce akan menyerahkan keamanan websitenya kepada Lembaga Otoritas Sertifikat (LOS) untuk dapat memberikan perlindungan penuh terhadap website e-commerce yang dimilikinya dari serangan para cybercrime.

Hal inilah yang pada akhirnya menyebabkan Lembaga Otoritas Sertifikat (LOS) mengalihkan resiko yang ia emban kepada pihak perusahaan asuransi, dengan perjanjian asuransi antara pihak Lembaga Otoritas Sertifikat (LOS) terhadap perusahaan asuransi.

Perjanjian asuransi antara lembaga otoritas sertifikat dengan perusahaan asuransi pada dasarnya merupakan asuransi pertanggungjawaban (liability insurance) karena yang diasuransikan adalah tanggung jawab dari LSO akibat terbongkarnya pengamanan dalam e-commerce yang menyebabkan salah satu pihak mengalami kerugian.

Kewajiban penanggung memberikan penggantian kepada tertanggung yaitu pemberian ganti rugi. Ganti rugi oleh penanggung dalam asuransi e-commerce diberikan bila tertanggung mengalami peristiwa di mana tertanggung gagal melaksanakan jasa profesinya atau oleh siapapun tertanggung dianggap bertanggung jawab secara hukum atas jasa.

Dalam secure electronic transaction objek yang dimaksud adalah kunci kriptografi yang memiliki kemungkinan untuk dicuri. Apabila dikaitkan dengan ketentuan yang tercantum dalam Pasal 256 KUHD tentang polis asuransi, maka perjanjian asuransi antara pihak lembaga otoritas sertifikat dengan perusahaan asuransi harus menyatakan $:^{7}$

1) Hari dibuatnya asuransi;

2) Nama orang yang menutup asuransi atas tanggungan sendiri atau atas tanggungan orang ketiga;

3) Suatu uraian yang cukup jelas mengenai benda yang dipertanggungkan;

4) Jumlah uang untuk berapa diadakan asuransi;

5) Bahaya-bahaya yang ditanggung oleh penanggung;

6) Saat bahaya mulai berlaku untuk tanggungan penanggung dan saat berakhirnya bahaya dimaksud;

7) Premi asuransi tersebut; dan Jumlah premi asuransi tergantung pada objek yang diasuransikan.

8) Pada umumnya, semua keadaan yang kiranya penting bagi penanggung untuk diketahuinya dan segala syarat yang diperjanjikan antara para pihak

Objek dari perjanjian asuransi e-commerce adalah sistem keamanan jaringan yaitu kunci kriptografi, tapi yang diasuransikan adalah tanggung jawab, yaitu tanggung jawab dari tertanggung yang dalam hal ini, adalah Lembaga Sertifikat Otoritas (LOS) untuk mengganti kerugian apabila kuncikunci yang diterbitkannya dicuri atau dipergunakan secara tidak sah oleh pihak yang tidak bertanggung jawab. Pengggunaan

Elisatris Gultom, Perlindungan Transaksi Elektronic ( e-commerce ) Melalui Lembaga Asuransi, Eprint Artikel Universitas Pajajaran, Bandung, 2011 hal 15 
kunci tersebut mengakibatkan konsumen kehilangan sejumlah uang yang disimpan di lembaga keuangan penerbit kartu atau bank. Sehingga dari analisa diatas, cukup jelas bahwa jenis asuransi yang terjadi antara Lembaga Otoritas Sertifikat (LOS) dengan perusahaan asuransi adalah asuransi pertanggungjawaban (liability insurance).

B. Subyek Dan Obyek Pertanggungan I Asuransi Dalam Transaksi Elektronik Melalui Internet (E-Commerce)

1) Pihak yang dapat menjadi Subyek Pertanggungan $/$ Asuransi dalam transaksi elektronik melalui internet (E-Commerce).

Di dalam asuransi dikenal adanya beberapa subyek (para pihak yang berkepentingan) yaitu, pihak penanggung dan tertanggung. Pemaparannya adalah sebagai berikut :

\section{a) Pihak Penanggung}

Penanggung adalah pihak yang bersedia untuk menerima dan mengambil alih resiko dari pihak tertanggung. Perjanijian tentang pertanggungan/asuransi terjadi antara kedua belah pihak, dimana penanggung bersedia dan berjanji untuk memberikan penggantian (konpensasi) kepada pihak tertanggung, apabila pihak tersebut mengalami kerugian, kerusakan, atau kehilangan keuntungan karena suatu peristiwa yang tidak tentu, sesuai yang disepakati di dalam perjanjian. Penanggung dapat berupa pribadi kodrati (perorangan), ataupun berupa badan hukum (perusahaan asuransi).

Apabila kita analisis dan kita kaitkan pada asuransi dalam dunia transaksi elektronik melalui internet, menurut penulis, yang menjadi pihak penanggung pada transaksi elektronik melalui internet (e-commerce)

$8 \quad$ Direktorat Jenderal Perdagangan dalam Negeri Republik Indonesia berkerja sama dengan LKHT-FHUI, Laporan Penelitian Tahap Pertama versi 1.04, Jakarta, 2001, hal. 161 adalah perusahaan asuransi yang menerima jasa asuransi dunia maya ( cyber assurance ). Contoh kongkrit perusahaan asuransi di Indonesia yang menerima jasa asuransi dunia maya, misalnya : PT. Asuransi Adira Dinamika (Adira Insurance).

\section{b) Pihak Tertanggung}

Tetanggung adalah pihak yang sesuai perjanjian akan ditanggung oleh pihak penanggung. Yang dapatmenjaditertanggung adalah pribadi kodrati (perorangan), sekelompok orang atau lembaga, badan Hukum termasuk perusahaan, atau siapapun yang dapat menderita kerugian.

Apabila kita analisis dan kita kaitkan pada asuransi dalam dunia transaksi elektronik melalui internet, menurut penulis, yang dapat menjadi pihak tertanggung dalam asuransi dunia maya adalah pihak Lembaga Otoritas Sertifikat ( LOS ) sebagai pihak yang dapat mengalami kerugian.

Lebih lanjut, berdasarkan pasal 1 butir (7) UU No. 40 tahun 2014 tentang Perasuransian,

"Usaha Reasuransi adalah usaha jasa pertanggungan ulang terhadap risiko yang dihadapi olehperusahaan asuransi, perusahaan penjaminan, atau perusahaan reasuransi lainnya."

maka ditemukan apa yang dikenal sebagai perusahaan reasuransi, yaitu perusahaan yang memberikan jasa dalam pertanggungan ulang terhadap resiko yang dihadapi oleh Perusahaan Asuransi Kerugian dan atau Perusahaan Asuransi Jiwa. Fungsi perusahaan Reasuransi disini adalah pihak (badan hukum bukan perorangan) yang menanggung kerugian yang dialami oleh Perusahaan Asuransi. Jadi dalam hubungannya perusahaan Asuransi adalah pihak tertanggung dan perusahaan reasuransi adalah pihak penanggung. Menurut penulis, resiko yang dihadapi oleh perusahaan asuransi berkenaan dengan asuransi dunia maya (cyber assurance) juga dapat di reasuransikan 
kepada pihak perusahaan reasuransi, misalnya : Perusahaan Asuransi Adira Finance sebagai pihak penanggung resiko kerugian Lembaga Otoritas Sertifikat Digital Symantec Corporation, mereasuransikan resikonya kepada perusahaan reasuransi, PT. Reasuransi Nasional Indonesia (PT. RNI).

2) Hal yang dapat menjadi Obyek Pertanggungan I Asuransi dalam transaksi elektronik melalui internet (E-Commerce).

Menurut Kitab Undang-Undang Hukum Dagang, hal yang dijadikan sebagai objek dalam suatu perjanjian asuransi adalah segala sesuatu yang merupakan isi atau bagian dari perjanjian tanggung menanggung antara penanggung dengan tertanggung yang mencakup benda dan jasa, jiwa dan raga, kesehatan manusia, tanggung jawab hukum serta semua kepentingan lainnya yang dapat hilang, rusak, rugi atau berkurang nilainya.

Objek asuransi menurut pasal 268 Kitab Undang-Undang Hukum Dagang. Adalah semua kepentingan yang :

a) Dapat dinilai dengan sejumlah uang.

b) Dapat takluk terhadap bermacammacam bahaya.

c) Tidak dikecualikan oleh undang-undang.

Berdasarkan penjelasan mengenai obyek pertanggungan asuransi secara umum menurut KUHD, maka jika kita analisis lebih mendalam, hal-hal yang dapat menjadi objek asuransi di dalam transaksi elektronik antara lain :

a) Transaksi Elektronik

Transaksi elektronik dapat dijadikan objek dari asuransi, dalam arti bahwa resiko yang perlu diasuransikan adalah kerugian yang terjadi dalam hal data pesan (message) yang hendak disampaikan, gagal sampai ke tempat tujuan karena sesuatu hal.

b) Sistem Keamanan Jaringan

Suatu otoritas sertifikat menyediakan sarana atau sistem untuk melakukan hubungan telekomunikasi antara para pengguna jasa. Hubungan komunikasi tersebut dapat terjadi kapan saja dan dapat dilakukan oleh siapa saja. Sistem yang disediakan oleh penyedia jasa tersebut dapat mengalami gangguan kerusakan, baik itu bersifat teknis sementara maupun yang bersifat memaksa karena bencana alam misalnya.

\section{Urgensi Peraturan Yang Khusus Mengatur Asuransi Dalam Transaksi Elektronik Melalui Internet (E-Commerce) Di Indonesia.}

Saat ini kegiatan transaksi bisnis yang menggunakan e-commerce pada dasarnya belum diatur secara tegas dan rinci, adapun sekumpulan peraturan internasional yang mengatur berkaitan dengan transaksi bisnis yang menggunakan e-commerce ini masih bersifat umum sehingga dalam rangka penyelesaian sengketa transaksi bisnis yang menggunakan e-commerce ini masih terjadi kekaburan hukum, keadaan dimana terjadinya kekaburan hukum dalam hal penyelesaian sengketa transaksi bisnis yang menggunakan e-commerce ini dapat dilihat dari ketiadaan aturan hukum yang jelas dan rinci sehingga hal ini akan menghasilkan ketidakmampuan beberapa aspek dalam menjalakan fungsi penegakkan hukum. Ketiadaan aturan hukum ini juga terjadi pada pengaturan hukum asuransi dalam transaksi bisnis e-commerce.

Pada dasarnya didalam Kitab Undangundang Hukum Dagang (KUHD) pasal 247 menyebutkan bahwa : Pertanggungan itu antara lain dapat mengenai: bahaya kebakaran; (KUHD 287 dst.) bahaya yang mengancam hasil pertanian yang belum dipanen; (KUHD 299 dst.) jiwa satu orang atau lebih; (KUHD 302 dst.) bahaya laut dan bahaya perbudakan; (KUHD 592 dst.) bahaya pengangkutan di darat, di sungai, dan perairan pedalaman. (KUHD 686 dst.). Apabila kita 
analisis, didalam pasal ini sudah jelas bahwa KUHD tidak mengenal adanya asuransi yang berkaitan dengan e-commerce. Bahkan regulasi terbaru yang dibuat oleh pemerintah Republik Indonesia yang mengatur tentang asuransi, yaitu Undang-Undang No. 40 Tahun 2014 tentang Perasuransian pun belum mengatur asuransi yang berkaitan dengan transaksi elektronik e-commerce.

Hal ini menurut penulis wajar, apabila kita melihat realita yang terjadi saat ini, karena urgensinya, asuransi yang melindungi transaksi electronic commerce tetap disediakan oleh beberapa perusahaan asuransi, dengan alasan transaksi e-commerce dapat menimbulkan kerugian bagi para pihak yang ada di dalamnya dan segala bentuk obyek yang dapat menimbulkan kerugian berarti dapat di asuransikan.

Perdagangan melalui Internet dengan menggunakan electronic commerce seperti dijelaskan sebelumnya memiliki banyak resiko. Resiko-resiko tersebut adalah : penyadapan, penipuan, penggandaan informasi transaksi, pencurian informasi rahasia, dan sebagainya. Dalam transaksi electronic commerce yang memanfaatkan kriptografi, kejahatan tersebut dapat dilakukan dengan beberapa cara, diantaranya adalah pembobolan kunci dan pencurian kunci.

Pembobolan kunci yang dimaksud adalah ketika si pembobol memakai berbagai cara untuk menemukan kunci yang sama dengan yang asli. Cara pembobolan yang paling umum digunakan adalah yang dikenal dengan istilah brute force attack, dimana, si pelaku mencoba berbagai kemungkinan hingga akhirnya ia menemukan kunci yang cocok.

Secure Electronic Transaction yang menggunakan kriptografi dalam pengamanannya adalah sistem perdagangan Internet yang relatif paling aman dari serangan-serangan yang mungkin dilakukan dalam Internet, antara lain pembobolan kunci dan pencurian kunci. Pembobolan kunci mungkin saja terjadi. Besar kecilnya kemungkinan ini ditentukan oleh panjangnya kunci. Semakin panjang kunci maka semakin sulit pula untuk membobolnya.

Di lain pihak khususnya di Indonesia, dalam konteks kekaburan hukum yang berkenaan dengan cyber insurance atau asuransi yang berkaitan dengan transaksi electronic commerce, bukan menjadikan masalah yang menyebabkan penegak hukum untuk tidak menyelesaikan suatu perkara yang diberikan kepadanya, bagaimanapun keadaannya sebagaimana yang tertuang dalam ketentuan pasal 22 AB dan pasal 14 Undang-Undang No. 14 tahun tahun 1970 yang kemudian diubah dengan pasal 16 Undang-Undang No. 4 Tahun 2004 tentang kekuasaan kehakiman mewajibkan "hakim untuk tidak menolak mengadili perkara yang diajukan kepadanya dengan alasan tidak lengkap, atau tidak jelas UndangUndang yang mengaturnya melainkan wajib mengadilinya."

Untuk mengatasinya dalam pasal 27 Undang-Undang No. 14 tahun 1970 yang kemudian dirubah dengan pasal 28 ayat 1 Undang-Undang No. 40 tahun 2004 menyebutkan : "hakim sebagai penegak hukum dan keadilan wajib menggali, mengikuti dan memahami nilai-nilai hukum yang hidup di dalam masyarakat". Artinya seorang hakim harus memiliki kemampuan dan keaktifan untuk menemukan hukum (rechtsvinding). Yang dimaksud dengan rechtvinding adalah proses pembentukkan hukum oleh hakim / aparat penegak hukum lainnya dalam penerapan peraturan umum terhadap peristiwa yang kongkrit. Dan hasil penemuan hukum menjadi dasar baginya untuk mengambil keputusan.

Namun, dalam penegakan hukum yang berkenaan dengan perkembangan teknologi dan informasi, seharusnya pengaturan 
tentang hal tersebut telah ditetapkan dalam peraturan tertulis, karena pada dasarnya, perkembangan teknologi akan terus menerus mengalami perkembangan yang signifikan, sehingga peraturan yang ada harus dapat mengikuti perkembangan teknologi yang ada, untuk dapat menjamin adanya kepastian hukum bagi masyrakat.

Perselisihan atau persengketaan dalam asuransi merupakan suatu keadaan yang tidak dikehendaki oleh para pihak baik tertanggung maupun penanggung. Artinya jika para pihak didalam asuransi senang bersengketa/berselisih, dapat dipastikan bahwa pihak tersebut tidak sehat. Akan tetapi dalam pergaulan di masyarakat apalagi yang menyangkut transaksi bisnis yang menggunakan e-commerce, dimana kita hidup di tengah orang yang berbeda tabiat dan kepentingan, kita pasti tidak akan bisa sama sekali untuk tidak berhadapan dengan perselisihan/ persengketaan. Perselisihan / persengketaan di dalam asuransi yang berkenaan dengan transaksi bisnis yang menggunakan e-commerce itu bisa disebabkan adanya wanprestasi dari para pihak baik penanggung maupun tertanggung, misalnya apabila klaim asuransi yang diajukan oleh tertanggung terlambat ataupun tidak dibayarkan oleh pihak penanggung, ataupun pihak tertanggung yang tidak mau membayarkan premi asuransi sesuai dengan polis yang telah disepakati pada saat pengajuan asuransi dalam transaksi e-commerce (cyber insurance).

Suatu perselisihan / sengketa dalam transaksi bisnis yang menggunakan ecommerce pada prinsipnya akan melibatkan beberapa Negara yang berbeda sehingga dalam penyelesaian perselisihan/sengketa, akan terdapat beberapa masalah yang berkaitan dengan hukum yang diberlakukan (applicable law) masalah tempat / forum penyelesaian perselisihan / sengketa, dan masalah eksekusi putusan pengadilan /
ADR. ${ }^{9}$

Dari uraian diatas, dapat diperhatikan bahwa perkembangan teknologi informasi, sadar atau tidak, telah memberikan dampak terhadap perkembangan hukum, hal ini merupakan tantangan sekaligus peluang yang harus dihadapi khususnya dibidang ekonomi dan hukum.

Perkembangan teknologi informasi telah melahirkan model transaksi baru dalam dunia perdagangan dan hal ini juga akan menimbulkan sengketa dalam transaksi bisnis tersebut. Untuk itu, menurut penulis diperlukan adanya revisi peraturan perundang-undangan tentang asuransi, yang didalamnya terdapat bab khusus, yang dapat memberikan pengaturan jelas mengenai asuransi yang berhubungan dengan transaksi bisnis e-commerce (cyber insurance), sehingga para pihak yang secara langsung berhubungan dengan hal ini, misalnya Bank, Lembaga Penyedia Layanan e-commerce, Lembaga Otoritas Sertifikat, serta konsumen yang biasa bertransaksi lewat dunia maya, akan mendapatkan kepastian hukum, sehingga tujuan hukum yang sebenarnya dapat terrealisasikan. Transaksi e-commerce tidak akan pernah luput dari risiko kerugian. Perjanjian asuransi antara lembaga otoritas sertifikat dengan perusahaan asuransi merupakan cara tepat untuk mengalihkan risiko kerugian, terutama pada transaksi e-commerce yang menggunakan kunci kriptografi dan secure electronic transaction.

Upaya ini sekaligus sebagai salah satu sarana perlindungan hukum bagi pihakpihak yang berkepentingan di dalamnya. Menurut penulis, sekalipun perjanjian cyber insurance antara lembaga otoritas sertifikat dengan perusahaan asuransi merupakan perjanjian asuransi yang sifatnya baru dan perlu diatur secara khusus di dalam Undang-

Yahya Ahmad Zein, Kontrak Elektronik dan Penyelesaian Sengketa Bisnis E-commerce, Bandung, Penerbit Mandar Maju, 2009, hal. 7 
Undang, namun dalam pemberlakuannya harus tetap memenuhi prinsip-prinsip yang ada dalam Kitab Undang- Undang Hukum Dagang sebagai dasar peraturan tentang asuransi di Indonesia.

\section{BAB IV PENUTUP}

\section{A. Kesimpulan}

Kesimpulan yang dapat penulis kemukakan pada penulisan makalah ilmiah ini adalah sebagai berikut :

1. Asuransi dalam transaksi jual beli melalui internet (e-commerce), jika di tinjau dari perspektif Kitab Undang-Undang Hukum Dagang (KUHD) dapat dibagi menjadi 2 bagian pokok pembahasan, yaitu :

a) Dari definisi asuransi dalam pasal 246 Kitab Undang-Undang Hukum Dagang (KUHD), dapat kita ketahui bahwa transaksi jual beli elektronik atau e-commerce merupakan obyek asuransi, karena segala kegiatan didalam transaksi elektronik atau ecommerce, dapat menimbulkan kehilangan, kerusakan, atau tidak mendapat keuntungan yang diharapkan bagi para pihak yang ada didalamnya. Asuransi dalam transaksi elektronik ini, kita kenal sebagai cyber assurance. Sedangkan, pihak yang paling bertanggung jawab atas adanya kerugian didalam transaksi electronic (e-commerce) adalah lembaga otoritas sertifikat (LOS) yang berperan sebagai pengaman transaksi elektronik, karena pihak perusahaan e-commerce akan menyerahkan keamanan websitenya kepada Lembaga Otoritas Sertifikat (LOS) untuk dapat memberikan perlindungan penuh terhadap website e-commerce yang dimilikinya dari serangan para cybercrime.

b) Apabila dikaitkan dengan ketentuan yang tercantum dalam pasal 256 KUHD tentang polis asuransi, maka perjanjian asuransi antara pihak lembaga otoritas sertifikat dengan perusahaan asuransi harus menyatakan:

1) Hari dibuatnya asuransi;

2) Nama orang yang menutup asuransi atas tanggungan sendiri atau atas tanggungan orang ketiga;

3) Suatu uraian yang cukup jelas mengenai benda yang dipertanggungkan;

4) Jumlah uang untuk berapa diadakan asuransi;

5) bahaya-bahaya yang ditanggung oleh penanggung;

6) Saat bahaya mulai berlaku untuk tanggungan penanggung dan saat berakhirnya bahaya dimaksud;

7) Premi asuransi tersebut; dan Jumlah premi asuransi tergantung pada objek yang diasuransikan.

8) Pada umumnya, semua keadaan yang kiranya penting bagi penanggung untuk diketahuinya dan segala syarat yang diperjanjikan antara para pihak.

Perjanjian asuransi antara lembaga otoritas sertifikat dengan perusahaan asuransi pada dasarnya merupakan asuransi pertanggungjawaban (liability insurance) karena yang diasuransikan adalah tanggung jawab dari LSO akibat terbongkarnya pengamanan dalam e-commerce yang menyebabkan salah satu pihak mengalami kerugian.

2. Pihak yang dapat menjadi Subyek Asuransi dalam transaksi elektronik commerce adalah :

a) Pihak penanggung pada transaksi elektronik melalui internet adalah Perusahaan asuransi yang menerima jasa asuransi dunia maya (cyber assurance).

b) Pihak tertanggung dalam asuransi dunia maya adalah pihak Lembaga Otoritas Sertifikat ( LOS ) sebagai pihak yang dapat mengalami kerugian. 
Sedangkan hal-hal yang dapat menjadi Objek asuransi di dalam e-commerce antara lain : Transaksi Elektronik dan Sistem Keamanan jaringan.

3. Asuransi dalam transaksi electronic commerce perlu diatur secara khusus di dalam peraturan perundang-undangan di Indonesia karena perkembangan teknologi informasi telah memberikan dampak terhadap perkembangan hukum, hal ini merupakan tantangan sekaligus peluang yang harus dihadapi khususnya dibidang ekonomi dan hukum. Perkembangan teknologi informasi telah melahirkan model transaksi baru dalam dunia perdagangan dan hal ini juga akan menimbulkan sengketa dalam transaksi bisnis tersebut. Untuk itu, menurut penulis diperlukan adanya revisi peraturan perundangundangan tentang asuransi, yang didalamnya terdapat bab khusus, yang dapat memberikan pengaturan jelas mengenai asuransi yang berhubungan dengan transaksi bisnis e-commerce (cyber insurance), sehingga para pihak yang secara langsung berhubungan dengan hal ini, misalnya Bank, Lembaga Penyedia Layanan e-commerce, Lembaga Otoritas Sertifikat, serta konsumen yang biasa bertransaksi lewat dunia maya, akan mendapatkan kepastian hukum, sehingga tujuan hukum yang sebenarnya dapat terrealisasikan. Transaksi e-commerce tidak akan pernah luput dari risiko kerugian. Perjanjian asuransi antara lembaga otoritas sertifikat dengan perusahaan asuransi merupakan cara tepat untuk mengalihkan risiko kerugian, terutama pada transaksi e-commerce yang menggunakan kunci kriptografi dan secure electronic transaction. Perjanjian cyber insurance antara lembaga otoritas sertifikat dengan perusahaan asuransi merupakan perjanjian asuransi yang sifatnya baru dan perlu diatur secara khusus di dalam undang-undang, namun dalam pemberlakuannya harus tetap memenuhi prinsip-prinsip yang ada dalam Kitab Undang-Undang Hukum Dagang ( KUHD ) sebagai dasar peraturan asuransi di Indonesia.

\section{B. Saran}

Saran yang dapat penulis kemukakan pada penulisan Artikel ilmiah ini adalah sebagai berikut:

1. Bagi perusahaan penyedia jasa e-commerce, hendaknya mempercayakan perlindungan website miliknya kepada Lembaga Ortoritas Sertifikat (LOS) yang dapat menjaminkeamanan website e-commerce dari segala bentuk kejahatan dunia maya (cybercrime). Lembaga Ortoritas Sertifikat (LOS) ini sesungguhnya sangat rentan terhadap kerugian, karena keamanan suatu website e-commerce merupakan tanggung jawab LOS. Sehingga menurut penulis, untuk mengurai resiko kerugian yang terjadi, hendaknya Lembaga Ortoritas Sertifikat (LOS) juga mengasuransikan resikonya kepada perusahaan asuransi, sehingga terjadi pengalihan resiko dari Lembaga Ortoritas Sertifikat (LOS) kepada perusahaan asuransi.

2. Bagi Pemerintah, perkembangan teknologi informasi telah melahirkan model transaksi baru dalam dunia perdagangan dan hal ini juga akan menimbulkan sengketa baru dalam transaksi bisnis e-commerce. Menurut penulis, pemerintah hendaknya melakukan revisi peraturan perundangundangan tentang asuransi yaitu UndangUndang Nomor 40 Tahun 2014 tentang Perasuransian, yang seharusnya terdapat bab khusus, yang dapat memberikan pengaturan jelas mengenai asuransi dalam transaksi bisnis e-commerce (cyber insurance), sehingga para pihak yang secara langsung berhubungan dengan hal ini, misalnya Bank, Lembaga Penyedia 
Layanan e-commerce, Lembaga Otoritas Sertifikat, serta konsumen yang biasa bertransaksi lewat dunia maya, akan mendapatkan kepastian hukum, sehingga tujuan hukum yang sebenarnya dapat terrealisasikan.

\section{DAFTAR PUSTAKA}

\section{Buku}

Liliana Tedjosaputro, 2016, Materi Kuliah Kebijakan Hukum Ekonomi, Pada Program Doktor Ilmu Hukum Untag, Semarang.

Wirjono Prodjodikoro, 1987, Hukum Asuransi di Indonesia, Penerbit PT Intermasa, Bandung.

Cholid Narbuko dan Abu Achmadi, 1997, Metode Penelitian, Bumi Pustaka, Jakarta.

Johnny Ibrahim, 2007 Teori, Metode dan Penelitian Hukum Normatif, Bayumedia Publising, Malang.

Yahya Ahmad Zein , 2009, Kontrak Elektronik dan Penyelesaian Sengketa Bisnis E-commerce, Penerbit Mandar Maju, Bandung.

\section{Artikel Ilmiah}

Elisatris Gultom, Perlindungan Transaksi Elektronic (e-commerce) Melalui Lembaga Asuransi, Eprint Artikel Universitas Pajajaran, Bandung

Direktorat Jenderal Perdagangan dalam Negeri Republik Indonesia berkerja sama dengan LKHT-FHUI, 2001, Laporan Penelitian Tahap Pertama versi 1.04, Jakarta.

\section{Internet}

Nanang Suryadi, 2011, Perkembangan e-commerce di Indonesia dan di Dunia,

www.ecom.lecture.ub.ac.id/2011/11/

November 2016 )

\section{Peraturan Perundang-undangan}

Kitab Undang-Undang Hukum Dagang

Kitab Undang-Undang Hukum Perdata

Undang-Undang Nomor 40 Tahun 2014

Tentang Perasuransian 